\title{
RESPON PERTUMBUHAN DAN PRODUKSI TANAMAN JAGUNG MANIS (Zea mays saccharata Sturt) AKIBAT PEMBERIAN BIO URINE DAN PENGATURAN JARAK TANAM
}

\author{
Nursayuti ${ }^{1}$ \\ ${ }^{1)}$ Dosen Fakultas Pertanian Program studi Agroteknologi Universitas Almuslim \\ Email: nursayuti1979@gmail.com
}

\begin{abstract}
ABSTRAK
Penelitian ini bertujuan untuk mengetahui pengaruh pemberian Bio Urine dan jarak tanam terhadap pertumbuhan dan produksi tanaman jagung manis. Penelitian ini dilaksanakan di Desa Meunasah Cut Kecamatan Peudada Kabupaten Bireuen yang dimulai dari bulan Mei sampai dengan bulan Agustus 2019. Rancangan yang dilakukan dalam penelitian ini adalah Rancangan Acak Kelompok (RAK) faktorial dengan dua faktor perlakuan yang diteliti. Faktor I : Bio Urine (B) dan faktor II : Jarak Tanam (J). Pengamatan yang diamati dalam penelitian ini meliputi tinggi tanaman, diameter batang, jumlah daun, berat tongkol berkelobot, berat tongkol tanpa kelobot, panjang tongkol dan berat 1000 butir. Pemberian Bio Urine berpengaruh sangat nyata terhadap tinggi tanaman umur 15 dan 45 HST, diameter batang umur 15 dan 30 HST, jumlah daun 30 dan 45 HST, berat tongkol berkelobot, berat tongkol tanpa kelobot, panjang tongkol dan jumlah baris per tongkol tanaman jagung manis. Perlakuan terbaik dijumpai pada konsentrasi Bio Urine 60 dan $100 \mathrm{ml} / 1$ air $\left(B_{1}\right.$ dan $\left.B_{2}\right)$. Pelakuan jarak tanam berpengaruh sangat nyata terhadap pertumbuhan tinggi tanaman umur 15 HST, diameter batang umur 45 HST, jumlah daun 15, 30 dan 45 HST dan berat tongkol berkelobot tanaman jagung manis. Perlakuan terbaik dijumpai pada jarak tanam $50 \mathrm{~cm}$ x $40 \mathrm{~cm}\left(\mathrm{~J}_{2}\right)$. Kombinasi perlakuan Bio Urine dan jarak tanam berpengaruh yang sangat nyata terhadap pertumbuhan tinggi tanaman umur 15 HST, diameter batang 15 HST, jumlah daun 15, 30 dan 45 HST, panjang tongkol, jumlah baris per tongkol dan berat 1000 butir tanaman jagung manis, akan tetapi tidak berpengaruh yata terhadap berat tongkol berkelobot dan berat tongkol tanpa kelobot. Perlakuan terbaik dijumpai pada kombinasi perlakuan Bio Urine konsentrasi $100 \mathrm{ml} / 1$ air dan jarak tanam $50 \mathrm{~cm}$ x $40 \mathrm{~cm}\left(\mathrm{~B}_{2} \mathrm{~J}_{2}\right)$
\end{abstract}

Kata Kunci : Bio Urine, Jarak Tanam, Jagung Manis

\section{PENDAHULUAN}

Jagung manis dengan nama ilmiah Zea mays saccharata Sturt termasuk ke dalam family Graminae, dicirikan oleh kadar gula yang lebih tinggi dibanding jenis jagung yang lain (Suprapto dan Rasyid, 2015). Jagung manis merupakan salah satu makanan pokok pengganti beras yang banyak dikonsumsi oleh masyarakat Indonesia. Produksi jagung manis di Indonesia masih terbilang rendah. Menurut data Badan Pusat Statistik (2017) di Bireuen, Aceh, produktivitas jagung di Indonesia mencapai 5,19 ton/ha, sedangkan menurut Syukur dan Rifianto (2013), tanaman jagung manis memiliki potensi hasil hingga 20 ton/ha. Penyebab rendahnya produksi jagung manis salah satunya disebabkan oleh tingkat kesuburan tanah yaitu kandungan unsur hara di dalam tanah yang belum mencukupi kebutuhan tanaman. Menurunnya produksi jagung manis di Aceh disebabkan olah kurangnya keinginan petani menanam tanaman jagung, sehingga menyebabkan rendahnya hasil jagung manis di Aceh, salah satunya dikarenakan belum maksimalnya pengetahuan petani dalam penggunaan teknologi produksi yang mendukung pertanian berkelanjutan dan semakin berkurangnya sumber daya lahan yang subur karena penggunaan pupuk anorganik yang berlebihan secara terus menerus.

Upaya mengatasi permasalahan tersebut maka perlu dilakukan tindakan pemupukan untuk penyediaan unsur hara bagi tanaman jagung manis. Unsur hara berperan penting dalam metabolisme tanaman salah satunya unsur nitrogen. Nitrogen merupakan unsur yang paling dibutuhkan tanaman untuk melangsungkan pertumbuhan vegetatifnya sehingga dapat memasuki fase selanjutnya yaitu generatif. Bio Urine merupakan alternatif dalam menyediakan unsur nitrogen.

Urine sapi yang biasanya hanya menjadi limbah peternakan akan lebih berguna bila dimanfaatkan sebagai pupuk cair untuk tanaman sebagi pengganti pupuk urea. Urine pada ternak sapi mengandung $92 \%$, nitrogen $1,00 \%$, fosfor $0,2 \%$, dan kalium $0,35 \%$ (Sutedjo, 2010). Di dalam urine sapi juga mengandung unsur hara fosfor yang berguna untuk pembentukan bunga dan buah, serta unsur hara kalium yang berfungsi untuk meningkatkan proses fotosintesis, aktivator bermacam sistem enzim, memperkuat perakaran, dan meningkatkan ketahanan tanaman terhadap penyakit (Sutedjo, 
2010). Hasil penelitian Kiki sanjaya, dkk (2015), menyatakan bahwa penggunaan Bio Urine $450 \mathrm{ML} /$ L air (pupuk cair urine sapi diaplikasikan pada 2, 4, 6 dan 8 MST) memberikan hasil terbaik pada pertumbuhan dan produksi tanaman jagung manis.

Dalam suatu sistem penanaman sering terjadi persaingan antara satu tanaman maupun antara tanaman dengan gulma untuk mendapatkan unsur hara, air, cahaya matahari maupun ruang tumbuh. Salah satu upaya tersebut dapat dilakukan melalui jarak tanam dapat diperoleh kerpatan tanaman yang optimum.

Jarak tanam yang rapat akan meningkatkan daya saing tanaman terhadap gulma karena tajuk tanaman menghambat pancaran cahaya ke permukaan lahan sehingga pertumbuhan gulma menjadi terhambat, disamping juga laju evaporasi dapat ditekan

\section{METODOLOGI PENELITIAN}

Penelitian ini dilaksanakan di Desa Meunasah Cut Kecamatan Peudada Kabupaten Bireuen dengan ketinggian tempat $2 \mathrm{~m}$ dpl. Penelitian ini dilaksanakan yang dimulai dari bulan Mei sampai dengan bulan Agustus 2019. Bahan yang digunakan dalam penelitian ini adalah air, benih jagung varietas Bonanza $\mathrm{F} 1$, Bio Urine, dan Urea, SP36, dan $\mathrm{KCl}$ sedangkan alat yang digunakan pada penelitian ini adalah meteran, tali rafia, parang babat, cangkul, garu, pisau, ember, gembor, handsprayer, alat tulis menulis, timbangan, kalkulator, jangka sorong

Penelitian ini menggunakan Rancangan Acak Kelompok RAK) pola faktorial yang terdiri dari dua faktor yaitu : pemberian bio urine dan jarak tanam. Adapun faktor yang diteliti adalah :Faktor 1 : Bio Urine (B) terdiri dari 3 taraf perlakuan : $\mathrm{B}_{0}=$ Tanpa bio urine ( kontrol), $\mathrm{B}_{1}=$ Bio urine $60 \mathrm{ml} / \mathrm{L}$ air, $\mathrm{B}_{2}$ $=$ Bio urine $100 \mathrm{ml} / \mathrm{L}$ air, sedangkan Faktor II adalah : Jarak Tanam $(\mathrm{J})$ terdiri dari 3 taraf perlakuan : $\mathrm{J}_{0}=70 \mathrm{~cm} \times 30 \mathrm{~cm}$ (kontrol), $\mathrm{J}_{1}=50 \mathrm{~cm}$ x $50 \mathrm{~cm}$, dan $\mathrm{J}_{2}=50 \mathrm{~cm}$ x $40 \mathrm{~cm}$.

Pengamatan yang diamati dalam penelitian ini adalah : tinggi tanaman, diameter batang, jumlah daun, berat tongkol berkelobot, berat tongkol tanpa kelobot, panjang tongkol dan berat 1000 butir.

\section{HASIL DAN PEMBAHASAN Pengaruh Pemberian Bio Urine dan Jarak tanam}

\section{Tinggi Tanaman (cm)}

Kombinasi perlakuan pemberian Bio Urine dan jarak tanam menunjukkan interaksi yang sangat nyata terhadap tinggi tanaman jagung manis umur 15 Hari Setelah Tanam. Rata-rata interaksi antara kombinasi perlakuan pemberian Bio Urine dan jarak tanam terhadap tinggi tanaman jagung manis umur 15 HST setelah diuji $\mathrm{BNJ}_{0,05}$ di sajikan pada Tabel 1 .

Tabel 1. Rata-rata Tinggi Tanaman Jagung Manis Umur 15 HST Akibat Interaksi Kombinasi Perlakuan Bio Urine dan Jarak Tanam

\begin{tabular}{lccc}
\hline \multirow{2}{*}{ Bio Urine } & \multicolumn{3}{c}{ Jarak Tanam } \\
\cline { 2 - 4 } & $\mathrm{J}_{0}=70 \times 30$ & $\mathrm{~J}_{1}=50 \times 50$ & $\mathrm{~J}_{2}=50 \times 40$ \\
\hline $\mathrm{B}_{0}=$ Kontrol & $33,48^{\mathrm{aA}}$ & $36,10^{\mathrm{bB}}$ & $36,76^{\mathrm{bA}}$ \\
$\mathrm{B}_{1}=60 \mathrm{ml} / 1$ air & $35,70^{\mathrm{aB}}$ & $35,36^{\mathrm{aA}}$ & $38,25^{\mathrm{bB}}$ \\
$\mathrm{B}_{2}=100 \mathrm{ml} / 1$ air & $36,06^{\mathrm{aB}}$ & $36,40^{\mathrm{aB}}$ & $41,50^{\mathrm{bC}}$ \\
\hline $\mathrm{BNJ}_{0,05}$ & \multicolumn{3}{c}{0,77} \\
\hline \multicolumn{2}{c}{ Keterangan : Angka yang diikuti oleh huruf yang sama pada lajur dan kolom yang sama tidak berbeda nyata pada taraf } \\
P $\leq 0,05$ (UJI BNJ), huruf besar dibaca vertikal dan huruf kecil dibaca horizontal
\end{tabular}

Tabel 1 diatas memperlihatkan kombinasi perlakuan pemberian Bio Urine dan jarak tanam menunjukkan interaksi yang sangat nyata terhadap tinggi tanaman jagung manis pada umur 15 HST. Tinggi tanaman tertinggi dijumpai pada kombinasi perlakuan Bio Urine $100 \mathrm{ml} / 1$ air dan jarak tanam $50 \mathrm{~cm}$ x $40 \mathrm{~cm}\left(\mathrm{~B}_{2} \mathrm{~J}_{2}\right)$. Hal ini disebabkan oleh pupuk Bio Urine dengan konsentarsi tersebut mampu bekerja sama dengan perlakuan jarak tanam, sehingga pemberian Bio Urine $100 \mathrm{ml}$ mampu meningkatkan pertumbuhan tinggi tanaman dan tidak terjadinya persaingan hara karena jarak tanam tersebut tidak terlalu rapat sehingga menurunkan kompetisi dalam menggunakan unsur hara dan sinar 
matahari. Dengan demikian, kebutuhan unsur hara terpenuhi, selain itu jarak yang renggang juga dapat menyebakan persaingan antar kanopi menjadi rendah.

Pemberian Bio Urine pada tanaman dengan jarak tanam optimum dibutuhkan mampu meningkatkan ketersediaan unsur hara $\mathrm{N}$ yang merupakan unsur hara utama bagi tanaman yang berperan dalam pertambahan tinggi tanaman (Lingga dan Marsono, 2014). Pengaturan jarak tanam yang optimum dibutuhkan untuk mengurangi terjadinya persaingan antar tanaman, maupun antar tanaman untuk mendapatkan unsur hara, air, cahaya matahari, maupun ruang tumbuh yang berpengaruh pada hasil yang maksimal. Sehingga bisa diduga bahwa penggunaan jarak tanam $50 \times 40$ $\mathrm{cm}$ berpengaruh terhadap pertumbuhan tinggi tanaman jagung manis.

\section{Diameter Batang (cm)}

Kombinasi perlakuan pemberian Bio Urine dan jarak tanam menunjukkan interaksi yang sangat nyata terhadap diameter batang tanaman jagung manis umur 15 hari setelah tanam. Rata-rata interaksi antara kombinasi perlakuan pemberian Bio Urine dan jarak tanam terhadap diameter batang tanaman jagung manis umur 15 HST setelah diuji $\mathrm{BNJ}_{0,05}$ di sajikan pada Tabel 2.

Tabel 2. Rata-rata Diameter Batang Tanaman Jagung Manis Umur 15 HST Akibat Interaksi Kombinasi Perlakuan Bio Urine dan Jarak Tanam

\begin{tabular}{lccc}
\hline \multirow{2}{*}{ Bio Urine } & \multicolumn{3}{c}{ Jarak Tanam } \\
\cline { 2 - 4 } & $\mathrm{J}_{0}=70 \times 30$ & $\mathrm{~J}_{1}=50 \times 50$ & $\mathrm{~J}_{2}=50 \times 40$ \\
\hline $\mathrm{B}_{0}=$ Kontrol & $0,73^{\mathrm{aA}}$ & $0,91^{\mathrm{aA}}$ & $0,66^{\mathrm{aA}}$ \\
$\mathrm{B}_{1}=60 \mathrm{ml} / 1$ air & $1,05^{\mathrm{aB}}$ & $0,97^{\mathrm{aA}}$ & $1,01^{\mathrm{aB}}$ \\
$\mathrm{B}_{2}=100 \mathrm{ml} / 1$ air & $0,66^{\mathrm{aA}}$ & $1,01^{\mathrm{bA}}$ & $1,18^{\mathrm{bB}}$ \\
\hline
\end{tabular}

$\mathrm{BNJ}_{0,05}$ 0,27

Keterangan : Angka yang diikuti oleh huruf yang sama pada lajur dan kolom yang sama tidak berbeda nyata pada taraf $\mathrm{P} \leq 0,05$ (UJI BNJ), huruf besar dibaca vertikal dan huruf kecil dibaca horizontal

Tabel 2 diatas memperlihatkan kombinasi perlakuan pemberian Bio Urine dan jarak tanam menunjukkan interaksi yang sangat nyata terhadap diameter batang tanaman jagung manis pada umur 15 HST. Diameter batang tanaman tertinggi dijumpai pada kombinasi perlakuan Bio Urine $100 \mathrm{ml} / \mathrm{l}$ air dan jarak tanam $50 \mathrm{~cm}$ x $40 \mathrm{~cm}\left(\mathrm{~B}_{2} \mathrm{~J}_{2}\right)$. Hal ini disebabkan oleh konsentrasi Bio Urine $100 \mathrm{ml} / 1$ air mampu menyediakan unsur hara dengan optimum yang dibutuhkan tanaman dalam perkembangan batang dan tidak terjadinya persaingan hara antara tanaman maupun gulma, karena perlakuan jarak tanaman $50 \mathrm{~cm}$ x $40 \mathrm{~cm}$ merupakan jarak tanam yang tepat dalam memicu pertumbuhan diameter batang tanaman.

Menurut Lingga dan Marsono (2014) bahwa penggunaan pupuk organik seperti Bio Urine dapat meningkatkan pertumbuhan tanaman. Hal ini disebabkan oleh unsur hara yang dibutuhkan tanaman tercukupi, maka laju pertumbuhan tanaman akan tinggi sehingga kondisi tersebut menguntungkan bagi tanaman. Disamping unsur hara tersedia dengan optimum pertumbuhan tanaman sangat di tentukan jarak tanamn, apabila jarak tanam tidak sempit maka intentitas cahaya tercukupi dengan optimum.

\section{Jumlah Daun (helai)}

Kombinasi perlakuan pemberian Bio Urine dan jarak tanam menunjukkan interaksi yang sangat nyata terhadap jumlah daun tanaman jagung manis umur 15, 30 dan 45 hari setelah tanam. Rata-rata interaksi antara kombinasi perlakuan pemberian Bio Urine dan jarak tanam terhadap jumlah daun tanaman jagung manis umur 15, 30 dan 45 HST setelah diuji $\mathrm{BNJ}_{0,05}$ di sajikan pada Tabel 3 .

Tabel 3. Rata-rata Jumlah Daun Tanaman Jagung Manis Umur 15, 30 dan 45 HST Akibat Interaksi Kombinasi Perlakuan Bio Urine dan Jarak Tanam

\begin{tabular}{cccc}
\hline \multirow{2}{*}{ Bio Urine } & \multicolumn{3}{c}{ Jarak Tanam } \\
\cline { 2 - 4 } & $\mathrm{J}_{0}=70 \times 30$ & $\mathrm{~J}_{1}=50 \times 50$ & $\mathrm{~J}_{2}=50 \times 40$ \\
\hline $\mathrm{B}_{0}=$ Kontrol & $6,00^{\mathrm{aA}}$ & Jumlah Daun Umur 15 HST & $6,05^{\mathrm{aA}}$
\end{tabular}




\begin{tabular}{|c|c|c|c|}
\hline $\mathrm{B}_{1}=60 \mathrm{ml} / \mathrm{lair}$ & $6,38^{\mathrm{aA}}$ & $6,61^{\mathrm{aA}}$ & $6,88^{\mathrm{aB}}$ \\
\hline $\mathrm{B}_{2}=100 \mathrm{ml} / 1 \mathrm{air}$ & $6,38^{\mathrm{aA}}$ & $6,55^{\mathrm{aA}}$ & $6,94^{\mathrm{aB}}$ \\
\hline \multirow[t]{2}{*}{$\mathrm{BNJ}_{0,05}$} & \multicolumn{3}{|c|}{0,58} \\
\hline & \multicolumn{3}{|c|}{ Jumlah Daun Umur 30 HST } \\
\hline $\mathrm{B}_{0}=$ Kontrol & $7,02^{\mathrm{aA}}$ & $7,89^{\mathrm{bB}}$ & $7,05^{\mathrm{aA}}$ \\
\hline $\mathrm{B}_{1}=60 \mathrm{ml} / 1$ air & $7,72^{\mathrm{aB}}$ & $7,61^{\mathrm{aA}}$ & $7,88^{\mathrm{aB}}$ \\
\hline $\mathrm{B}_{2}=100 \mathrm{ml} / 1 \mathrm{air}$ & $7,38^{\mathrm{aB}}$ & $7,55^{\mathrm{aA}}$ & $7,61^{\mathrm{aB}}$ \\
\hline \multirow[t]{2}{*}{$\mathrm{BNJ}_{0,05}$} & \multicolumn{3}{|c|}{0,29} \\
\hline & \multicolumn{3}{|c|}{ Jumlah Daun Umur 45 HST } \\
\hline $\mathrm{B}_{0}=$ Kontrol & $7,94^{\mathrm{aA}}$ & $8,55^{\mathrm{bA}}$ & $8,04^{\mathrm{aA}}$ \\
\hline $\mathrm{B}_{1}=60 \mathrm{ml} / 1$ air & $8,33^{\mathrm{aB}}$ & $8,61^{\mathrm{bB}}$ & $8,88^{\mathrm{bB}}$ \\
\hline $\mathrm{B}_{2}=100 \mathrm{ml} / 1 \mathrm{air}$ & $8,06^{\mathrm{aA}}$ & $8,36^{\mathrm{bA}}$ & $9,10^{\mathrm{cC}}$ \\
\hline $\mathrm{BNJ}_{0.05}$ & \multicolumn{3}{|c|}{0,17} \\
\hline
\end{tabular}

Tabel 3 diatas memperlihatkan kombinasi perlakuan pemberian Bio Urine dan jarak tanam menunjukkan interaksi yang sangat nyata terhadap jumlah daun tanaman jagung manis pada umur 15 , 30 dan 45 HST. Jumlah daun tanaman tertinggi 15 dan 45 HST dijumpai pada kombinasi perlakuan Bio Urine $100 \mathrm{ml} / 1$ air dan jarak tanam $50 \mathrm{~cm}$ x $40 \mathrm{~cm}\left(\mathrm{~B}_{2} \mathrm{~J}_{2}\right)$ dan pada umur 30 dijumpai pada kombinasi perlakuan kontrol dan jarak tanam $50 \mathrm{~cm}$ x $50 \mathrm{~cm}\left(\mathrm{~B}_{0} \mathrm{~J}_{1}\right)$. Hal ini disebabkan oleh konsentrasi Bio Urine tersebut mampu menyediakan unsur hara dengan cukup yaitu $\mathrm{N}, \mathrm{P}$ dan $\mathrm{K}$ dan juga disebabkan oleh jarak tanam tersebut berpengaruh terhadap besarnya intensitas cahaya dan ketersediaan unsur hara yang dibutuhkan bagi tanaman.

Sutedjo (2010) menyatakan bahwa pemberian Bio Urine mampu memberikan pertumbuhan pada parameter jumlah daun lebih banyak. Dharmayanti dkk., (2013) menjelaskan bahwa pemberian Bio Urine mampu menambah hara tanah seperti K tersedia dan N-Total tanah tertinggi. Penambahan Bio Urine yang telah di fermentasi memiliki kandungan N, P dan K. Populasi tanaman yang relatif rendah memungkinkan tanaman jagung manis tidak saling menaungi sehingga dapat memenuhi kebutuhan radiasi matahari dan nutrisi.

\section{Panjang Tongkol (cm)}

Kombinasi perlakuan pemberian Bio Urine dan jarak tanam menunjukkan interaksi yang sangat nyata terhadap panjang tongkol tanaman jagung manis. Rata-rata interaksi antara kombinasi perlakuan pemberian Bio Urine dan jarak tanam terhadap panjang tongkol tanaman jagung manis setelah diuji $\mathrm{BNJ}_{0,05}$ di sajikan pada Tabel 21.

Tabel 4 Rata-rata Panjang Tongkol Tanaman Jagung Manis Akibat Interaksi Kombinasi Perlakuan Bio Urine dan Jarak Tanam

\begin{tabular}{lccc}
\hline \multirow{2}{*}{ Bio Urine } & \multicolumn{3}{c}{ Jarak Tanam } \\
\cline { 2 - 4 } & $\mathrm{J}_{0}=70 \times 30$ & $\mathrm{~J}_{1}=50 \times 50$ & $\mathrm{~J}_{2}=50 \times 40$ \\
\hline $\mathrm{B}_{0}=$ Kontrol & $15,37^{\mathrm{aA}}$ & $15.33^{\mathrm{aA}}$ & $15.85^{\mathrm{aB}}$ \\
$\mathrm{B}_{1}=60 \mathrm{ml} / 1$ air & $16.61^{\mathrm{bB}}$ & $15,75^{\mathrm{bA}}$ & $14,63^{\mathrm{aA}}$ \\
$\mathrm{B}_{2}=100 \mathrm{ml} / 1$ air & $15,09^{\mathrm{aA}}$ & $16,51^{\mathrm{bB}}$ & $16,99^{\mathrm{bC}}$ \\
\hline $\mathrm{BNJ}_{0,05}$ & \multicolumn{3}{c}{0,73}
\end{tabular}

$\mathrm{BNJ}_{0,05}$

Keterangan : Angka yang diikuti oleh huruf yang sama pada lajur dan kolom yang sama tidak berbeda nyata pada taraf $\mathrm{P} \leq 0,05$ (UJI BNJ), huruf besar dibaca vertikal dan huruf kecil dibaca horizontal

Tabel 4 diatas memperlihatkan kombinasi perlakuan pemberian Bio Urine dan jarak tanam menunjukkan interaksi yang sangat nyata terhadap panjang tongkol tanaman jagung manis. Panjang tongkol tanaman tertinggi dijumpai pada kombinasi perlakuan Bio Urine $100 \mathrm{ml} / \mathrm{l}$ air dan jarak tanam $50 \mathrm{~cm}$ x $40 \mathrm{~cm}\left(\mathrm{~B}_{2} \mathrm{~J}_{2}\right)$. Hal ini disebabkan oleh kombinasi perlakuan Bio Urine dan jarak tanam yang sangat mendukung terhadap pertumbuhan panjang tongkol tanaman jagung manis, karena pada konsentrasi tersebut mampu menyediakan unsur hara terhadap tanaman jagung manis. Novizan (2012) 
yang menyatakan bahwa penambahan bahan organik selain meningkatkan jumlah hara makro dan mikro juga dapat meningkatkan kapasitas tukar kation tanah yang akhirnya akan berpengaruh positif untuk pertumbuhan tanaman. Tanaman jagung tidak akan memberikan hasil maksimal apabila unsur hara yang diperlukan tidak cukup tersedia.

Jarak tanaman $50 \mathrm{~cm} \times 40 \mathrm{~cm}$ mendukung dalam proses terjadinya fotosintat yang ditranslokasikan ke bagian tongkol. Semakin besar fotosintat yang ditranslokasikan ke tongkol maka semakin meningkat pula pertumbuhan tongkol tanaman jagung manis. Salisbury dam Ross (2014) menyatakan bahwa luas daun tanaman merupakan suatu faktor yang menentukan jumlah energi matahari yang dapat diserap oleh daun dan akan menentukan besarnya fotosintat yang dihasilkan. Dengan mengatur jarak tanam yang $50 \mathrm{~cm}$ x $40 \mathrm{~cm}$ cahaya dapat dimanfaatkan dengan efisien mungkin, maka akan diperoleh hasil fotosintesis yang semakin besar juga yang dapat mempengaruhi pertumbuhan tongkol tanaman jagung manis

\section{Jumlah Baris Per Tongkol (Baris)}

Kombinasi perlakuan pemberian Bio Urine dan jarak tanam menunjukkan interaksi yang nyata terhadap jumlah baris per tongkol tanaman jagung manis. Rata-rata interaksi antara kombinasi perlakuan pemberian Bio Urine dan jarak tanam terhadap jumlah baris per tongkol tanaman jagung manis setelah diuji $\mathrm{BNJ}_{0,05}$ di sajikan pada Tabel 5

Tabel 5. Rata-rata Jumlah Baris Per Tongkol Tanaman Jagung Manis Akibat Interaksi Kombinasi Perlakuan Bio Urine dan Jarak Tanam

\begin{tabular}{lccc}
\hline \multirow{2}{*}{ Bio Urine } & \multicolumn{3}{c}{ Jarak Tanam } \\
\cline { 2 - 4 } & $\mathrm{J}_{0}=70 \times 30$ & $\mathrm{~J}_{1}=50 \times 50$ & $\mathrm{~J}_{2}=50 \times 40$ \\
\hline $\mathrm{B}_{0}=$ Kontrol & $15,55^{\mathrm{bB}}$ & $14,33^{\mathrm{aA}}$ & $14,66^{\mathrm{aA}}$ \\
$\mathrm{B}_{1}=60 \mathrm{ml} / 1$ air & $15,44^{\mathrm{aB}}$ & $14,66^{\mathrm{aA}}$ & $15,88^{\mathrm{bB}}$ \\
$\mathrm{B}_{2}=100 \mathrm{ml} / 1$ air & $13,11^{\mathrm{aA}}$ & $14,22^{\mathrm{bA}}$ & $14,77^{\mathrm{bA}}$ \\
\hline $\mathrm{BNJ}_{0,05}$ & \multicolumn{3}{c}{1,01} \\
\hline
\end{tabular}

Keterangan : Angka yang diikuti oleh huruf yang sama pada lajur dan kolom yang sama tidak berbeda nyata pada taraf $\mathrm{P} \leq 0,05$ (UJI BNJ), huruf besar dibaca vertikal dan huruf kecil dibaca horizontal

Tabel 5 diatas memperlihatkan kombinasi perlakuan pemberian Bio Urine dan jarak tanam menunjukkan interaksi yang sangat nyata terhadap jumlah baris per tongkol tanaman jagung manis. Jumlah baris per tongkol tanaman tertinggi dijumpai pada kombinasi perlakuan Bio Urine $60 \mathrm{ml} / \mathrm{l}$ air dan jarak tanam $50 \mathrm{~cm} \times 40 \mathrm{~cm}\left(\mathrm{~B}_{1} \mathrm{~J}_{2}\right)$. Hal ini disebabkan oleh penambahan Bio Urine dengan konsentrasi $60 \mathrm{ml} / 1$ air mampu menyediakan unsur $\mathrm{N}, \mathrm{P}$ dan $\mathrm{K}$ dengan cukup dan didukung oleh jarak tanam yang luas sehingga dengan adanya pemberian pupuk Bio Urine $60 \mathrm{ml}$ tidak menyebabkan persaingan antar tanaman dalam memperebutkan unsur hara, air dan cahaya

Harjadi (2016) menyatakan bahwa pembentukan dan pengisian buah sangat dipengaruhi oleh unsur hara N, P, K yang akan digunakan dalam proses fotosintesis penyusun karbohidrat, lemak, protein, mineral, dan vitamin yang akan ditranslokasikan kebagian penyusun buah. Suprapto (2014) juga mengatakan bahwa unsur $\mathrm{N}$ diserap tanaman selama masa pertumbuhan sampai pematangan biji, tetapi pangambilan unsur $\mathrm{N}$ tidak sama pada setiap fase pertumbuhan, sehingga dengan demikian tanaman jagung menghendaki tersedianya unsur $\mathrm{N}$ secara terus menerus pada semua stadia pertumbuhan sampai pada saat pematangan biji.

Menurut Marschner (2013) jumlah baris biji per tongkol yang dihasilkan tanaman jagung manis selain dipengaruhi oleh faktor genetik dipengaruhi juga oleh diameter tongkol, hal ini disebabkan barisan biji jagung tersebut tumbuh melingkari tongkol jagung sehingga semakin besar diameter tongkol maka semakin besar pula peluang terbentuknya barisan biji pada tongkol.

Jarak tanam yang luas dapat membantu tanaman dalam memperoleh cahaya matahari air dan unsur hara yang optimal, sehingga fotosintesis dapat berjalan dengan maksimal mengakibatkan fotosintat yang dihasilkan lebih tinggi. Hasil penelitian Silaban, dkk. (2013) menunjukan bahwa produksi pertanaman tertinggi diperoleh pada jarak tanam $50 \mathrm{~cm}$ x $40 \mathrm{~cm}$, hal ini disebabkan jarak tanam tersebut lebih besar sehingga tanaman mendapatkan unsur hara yang cukup untuk melakukan proses assimilasi. 


\section{Berat 1000 Butir (g)}

Kombinasi perlakuan pemberian Bio Urine dan jarak tanam menunjukkan interaksi yang sangat nyata terhadap berat 1000 butir tanaman jagung manis. Rata-rata interaksi antara kombinasi perlakuan pemberian Bio Urine dan jarak tanam terhadap berat 1000 butir tanaman jagung manis setelah diuji $\mathrm{BNJ}_{0,05}$ di sajikan pada Tabel 6 .

Tabel 6. Rata-rata Berat 1000 Butir Tanaman Jagung Manis Akibat Interaksi Kombinasi Perlakuan Bio Urine dan Jarak Tanam

\begin{tabular}{lccc}
\hline \multirow{2}{*}{ Bio Urine } & \multicolumn{3}{c}{ Jarak Tanam } \\
\cline { 2 - 4 } & $\mathrm{J}_{0}=70 \times 30$ & $\mathrm{~J}_{1}=50 \times 50$ & $\mathrm{~J}_{2}=50 \times 40$ \\
\hline $\mathrm{B}_{0}=$ Kontrol & $66,63^{\mathrm{bB}}$ & $55,13^{\mathrm{aA}}$ & $56,54^{\mathrm{aA}}$ \\
$\mathrm{B}_{1}=60 \mathrm{ml} / 1$ air & $66,06^{\mathrm{aB}}$ & $58,05^{\mathrm{aA}}$ & $57,98^{\mathrm{aA}}$ \\
$\mathrm{B}_{2}=100 \mathrm{ml} / 1$ air & $40,81^{\mathrm{aA}}$ & $70,13^{\mathrm{bB}}$ & $72,56^{\mathrm{bB}}$ \\
\hline $\mathrm{BNJ}_{0,05}$ & \multicolumn{3}{c}{8,21} \\
\hline
\end{tabular}

Keterangan : Angka yang diikuti oleh huruf yang sama pada lajur dan kolom yang sama tidak berbeda nyata pada taraf $\mathrm{P} \leq 0,05$ (UJI BNJ), huruf besar dibaca vertikal dan huruf kecil dibaca horizontal

Tabel 6 diatas memperlihatkan kombinasi perlakuan pemberian Bio Urine dan jarak tanam menunjukkan interaksi yang sangat nyata terhadap jumlah baris per tongkol tanaman jagung manis. Jumlah baris per tongkol tanaman tertinggi dijumpai pada kombinasi perlakuan Bio Urine $100 \mathrm{ml} / \mathrm{l}$ air dan jarak tanam $50 \mathrm{~cm} \times 40 \mathrm{~cm}\left(\mathrm{~B}_{1} \mathrm{~J}_{2}\right)$. Hal ini disebabkan oleh pemberian Bio Urine dengan konsentasi $100 \mathrm{ml} / \mathrm{l}$ air dapat menyediakan unsur hara $\mathrm{P}$ dan $\mathrm{K}$ pada tanah sehingga unsur $\mathrm{P}$ dan $\mathrm{K}$ cukup untuk kebutuhan tanaman jagung dalam memicu berat 1000 biji dan pada jarak tanam $50 \mathrm{~cm} \mathrm{x}$ $40 \mathrm{~cm}$ memeliki ruang yang lebih luas sehingga menybabkan penggunaan cahaya dan unsur hara tidak terjadi persaingan antara tanaman.

Unsur hara $\mathrm{P}$ dan $\mathrm{K}$ yang terkandung dalam pupuk memberikan peranan dalam pertumbuhan berat 1000 biji. Novizan (2012), menyatakan bahwa salah satu fungsi kalium adalah memperbaiki kualitas buah pada masa generatif. Selanjutnya Suetoro, dkk (2007), menyatakan bahwa hara P dan K mempengaruhi terhadap hasil tanaman jagung manis terutama pada pembentukan biji, karena hara yang diserap oleh tanaman akan dipergunakan untuk pembentukan protein, karbohidrat, dan lemak yang nantinya akan disimpan dalam biji sehingga akan meningkatkan bobot biji.

Hidayat (2008) yang menyatakan pengaturan jarak tanam dengan kepadatan tertentu bertujuan memberi ruang tumbuh pada tiap-tiap tanaman agar tumbuh dengan baik. Jarak tanam akan mempengaruhi kepadatan dan efisiensi penggunaan cahaya, persaingan diantara tanaman dalam penggunaan air dan unsur hara sehingga akan mempengaruhi produksi tanaman.

\section{KESIMPULAN}

1. Pemberian Bio Urine berpengaruh sangat nyata terhadap tinggi tanaman umur 15 dan 45 HST, diameter batang umur 15 dan 30 HST, jumlah daun 30 dan 45 HST, berat tongkol berkelobot, berat tongkol tanpa kelobot, panjang tongkol dan jumlah baris per tongkol tanaman jagung manis. Perlakuan terbaik dijumpai pada konsentrasi Bio Urine 60 dan $100 \mathrm{ml} / 1$ air $\left(\mathrm{B}_{1}\right.$ dan $\left.\mathrm{B}_{2}\right)$.

2. Pelakuan jarak tanam berpengaruh sangat nyata terhadap pertumbuhan tinggi tanaman umur 15 HST, diameter batang umur 45 HST, jumlah daun 15, 30 dan 45 HST dan berat tongkol berkelobot tanaman jagung manis. Perlakuan terbaik dijumpai pada jarak tanam $50 \mathrm{~cm}$ x $40 \mathrm{~cm}$ $\left(\mathrm{J}_{2}\right)$

3. Kombinasi perlakuan Bio Urine dan jarak tanam berpengaruh yang sangat nyata terhadap pertumbuhan tinggi tanaman umur 15 HST, diameter batang 15 HST, jumlah daun 15, 30 dan 45 HST, panjang tongkol, jumlah baris per tongkol dan berat 1000 butir tanaman jagung manis, akan tetapi tidak berpengaruh nyata terhadap berat tongkol berkelobot dan berat tongkoltanpa kelobot. Perlakuan terbaik dijumpai pada kombinasi perlakuan Bio Urine konsentrasi $100 \mathrm{ml} / \mathrm{l}$ air dan jarak tanam $50 \mathrm{~cm} \times 40 \mathrm{~cm}\left(\mathrm{~B}_{2} \mathrm{~J}_{2}\right)$

\section{DAFTAR PUSTAKA}

Badan Pusat Statistika Bireuen. 2017. Bireuen Regency In Figures. Dinas Pertanian Kabupaten Bireuen. Bireuen 
Dharmayanti, N.K.S., A.A.N. Supadma, dan I.D. M. Arthagama. 2013. Pengaruh Pemberian Biourine dan Dosis Pupuk Anorganik (N,P,K) Terhadap Beberapa Sifat Kimia Tanah Pegok dan Hasil Tanaman Bayam (Amaranthus sp.). Agroekoteknologi Tropika. 2(3):165- 174

Harjadi, S. S. M. M., 2016. Pengantar Agronomi. Gramedia Pustaka Utama, Jakarta

Hidayat, N., 2008. Pertumbuhan dan Prodiksi Kacang Tanah (Arachis hypogea L.) Varietas Lokal Madura Pada Berbagai Jarak Tanam dan Dosis Pupuk Fosfor. Serial online. diakses pada tanggal 3 April 2014.

Kiki S., Hamidah H., dan Alida L. 2015. Pemberian Pupuk P Dan Zn Untuk Meningkatkan Ketersediaan P Dan Zn Di Tanah Sawah. Jurnal Agroekoteknologi. Fakultas Pertanian, USU, Medan.

Lingga, P. dan Marsono. 2014. Petunjuk Penggunaan Pupuk. Penebar Swadaya. Jakarta.

Marschner H. 2013. Mineral Nutrition of Higher Plants. Academic Press. London.

Novizan 2012. Petunjuk Pemupukan yang Efektif. Agro Media Pustaka, Jakarta.

Salisbury, F.B. dan Ross, C.W. 2014. Fisiologi Tumbuhan.Penerbit ITB Bandung.

Silaban, E.T. Purba, E. dan Ginting J. 2013. Pertumbuhan Dan Produksi Jagung Manis (Zea mays sacaratha Sturt. L) Pada Berbagai Jarak Tanam Dan Waktu Olah Tanah. Jurnal Online Agroekoteknologi. Juni 2013. 1(3) ISSN No. 2337-6597.

Suprapto dan Rasyid. M. 2012. Bertanam Jagung. Jakarta : Penebar Swadaya.

Soetoro, Y. Soelaiman dan Iskandar. 2012. Budidaya Tanaman Jagung. Pusat Penelitian dan Pengembangan Tanaman Pangan. Bogor.

Syukur, M.dan A. Rifianto. 2013. Jagung Manis. Penebar Swadaya. Jakarta. 